\title{
KNOWLEDGE LEVEL AND SELF-CONFIDENCE ON THE COMPUTATIONAL THINKING SKILLS AMONG SCIENCE TEACHER CANDIDATES
}

\author{
Titik Rahayu" $^{* 1}$ Kamisah Osman ${ }^{2}$ \\ ${ }^{1,2}$ Fakulti Pendidikan, Universiti Kebangsaan Malaysia, 43600 UKM Bangi, Selangor, Malaysia \\ *Correspondence Address: P91583@ sisiwa.ukm.edu.my
}

Received: February $16^{\text {th }}, 2019$. Accepted: April 24 ${ }^{\text {th }}$, 2019. Published: April 29 ${ }^{\text {th }}, 2019$

\begin{abstract}
The trending topic in today's education is computational thinking skills which are used to help to solve complicated problems easier. This study aims to identify the level of knowledge and self-confidence of science teacher candidates (physics and biology) on computational thinking skills. The survey research design was used through a mixed-method approach by combining quantitative and qualitative approaches. The quantitative study involved 1016 randomly selected groups of science teachers while in the qualitative study, eight science teachers were chosen based on the scores obtained from the quantitative study. The questionnaire was used as a quantitative data collecting technique to analyze descriptive statistics. Then, an interview was used as the qualitative data collecting technique and was analyzed through theme creation. The findings show that science teacher candidates have a high level of knowledge and self-confidence. The implication of this study is very important for teacher candidates because computational thinking can help to facilitate problems solving in everyday life. Teacher candidates need to be given knowledge and understanding of computational thinking skills, to have readiness and self-confidence in facing the challenges of the learning in the $21^{\text {st }}$-century.
\end{abstract}

(C) 2019 Physics Education, UIN Raden Intan Lampung, Indonesia

Keywords: computational thinking skills, knowledge, self-confidence, physics science teachers candidate.

\section{INTRODUCTION}

Computational thinking skills are defined as a set of problem-solving skills based on computer techniques required for almost all careers, not just scientists but also in other fields, such as doctors, teachers, or farmers (Figueiredo \& Alberto, 2017). Computational thinking is defined by Wing (2011) as a thought process involving problem formulation and expressing solutions through information processing. It is explained further by Aho (2012), who states computational thinking as a thought process involving problem formulation so that students can solve problems through calculation and generalization steps. However, the solution varies depending on the computing system and the problems that individuals face.

The study of computational thinking skills has been carried out by previous researchers. However, previous studies focused more on students (Barr \& Chris,
2011; Grover \& Pea, 2013; Yadav, Zhou, Mayfield, Hambrusch, \& Korb, 2011), a study from (Belanger, Christenson, Hannah, \& Lopac, 2018) also examine the computational thinking skills among 10-16year-old students; it focused on problemsolving. However, research among teacher candidates has not been conducted by researchers (Yadav et al., 2011). It was supported by Yadav, Mayfield, Zhou, Hambrusch, \& Korb (2014) who say that the integration of computational thinking skills at university level is still low. This is illustrated by the observation of researchers on science teacher candidates in one university in Indonesia through the dissemination of google form questionnaire. The results indicate that teacher candidates have less knowledge about computational thinking skills. In fact, most science teacher candidates have never been exposed to computational thinking (Titik \& Kamisah, 2018). It is supported by 
Meritxell Estebanell, Juan González, Marta Peracaula, \& Víctor Lopez (2017), that the present day, in the faculty of education, has not yet formed a teacher candidates who are ready to teach computational thinking at a real school in the future, because to teach computational thinking requires knowledge and the teacher's self-confidence.

The knowledge and self-confidence in computational thinking skills among teacher candidates have been studied recently, but still very few studies specifically explain their knowledge and self-confidence. For example, a study by (Matt \& Falkner, 2015) that examine the pedagogical capability enhancement (including understanding, ability, technological knowledge, and selfconfidence) computational thinking of school teachers. A self-confidence study found that 18 out of 32 teacher candidates $(56 \%)$ at Australian universities expressed uncertainty and were not convinced to teach computational thinking skills in the real class. Two researchers suggested that teachers lack understanding, ability, technological knowledge, and selfconfidence in understanding the concept of computational thinking (Bower et al., 2017; Sentance \& Andrew, 2015). Overall, it is concluded that studies related to the knowledge and self-confidence of computational thinking skills among the teacher candidates have not been specifically identified.

Angeli \& Jaipal Jamani (2018), explain that systematic reviews on the teaching of computational thinking skills among teachers are still lacking in scientific articles as teaching references. Thus, in previous years, there was evidence that the teaching at the faculty of higher education lacked the knowledge and skills to teach computational thinking skills among teacher candidates (Yadav et al., 2014). In Indonesia, a preliminary study was conducted by a researcher at the State Islamic University Raden Intan Lampung. The results showed that there are 31 people
(51.7\%) had never heard of computational thinking skills, 8 (13.3\%) were doubtful, and $21(35 \%)$ had ever heard about it. Candidates claim that they are less convinced of computational thinking skills due to lack of knowledge (Titik \& Kamisah, 2018). This finding is supported by a recent study by (Sands, Yadav, \& Good, 2018), that there are still very few teachers who have the knowledge and awareness of how computational thinking skills can be carried out in their classroom.

Based on the issues that the researchers have done earlier, this investigation is important in Indonesia. The aim of the study is in line with the 2013 curriculum policy which requires that in the learning implementation, the students should be given the freedom to think and solve the problems that are being faced, develop strategies to solve problems and propose ideas freely and openly (Josip \& Sinambela, 2013). Computational thinking skills are one of the most useful skills to assist teachers and potential teacher candidates in understanding and to strengthen the teaching and learning required in the 2013 curriculum. According to Machali (2014), the policy of the 2013 curriculum change is based on internal and external challenges faced by Indonesian people to prepare productive, creative, innovative, and effective generations. Ozcinar (2017) recommends that future studies need to examine computational thinking in the context of educational technology, investigate its adjustment and use in professional life, and the relevant concepts should be included in the definition of the future.

Computational thinking skills need to be introduced in Indonesia. This is in line with Endarta (2014) who views that computational thinking skills are essential and in line with the goals of 2013 curriculum learning in Indonesia, as it has been widely carried out in countries around the world. For example, China is an innovative talent advocate in various 
disciplines (Long, Jiehui, \& Zhanli, 2013). In England, it is as one of the subjects of the country's curriculum (Department for Education England, 2014). In South Korea, it is one of the new curriculum subjects in 2018, which includes digital literacy, computational thinking, and programming (Jeongwon, Sangjin, \& Youngjun, 2015). Education in Indonesia is responsible for increasing knowledge and self-confidence in computational thinking skills, such as by incorporating into the education curriculum and making one of the compulsory subjects of the faculty. As per findings found by Erdogan \& Koseoglu (2012), the nature of science should be emphasized in the science curriculum to help every citizen in the country become lifelong learners and have sufficient scientific literacy level.

Researchers have been conducting studies on computational thinking skills in various fields, ranging from education or career. However, based on the analysis it is found that in this study, there is a significant difference specifically about the explanation of knowledge and selfconfidence in computational thinking skills. Most previous researchers did not discuss specifically and did not directly link the relationship between the knowledge and the self-confidence of the prospective teacher. Therefore, this study is a new study in the field of education.

\section{METHOD}

This research applied a survey design with a mixed-method approach which combined quantitative approach and qualitative approach. As suggested by $\mathrm{Wu}$ (2018), studies related to computational thinking in science need to be collected by using a design of mix to collect quantitative and qualitative data. The use of mixed methods is intended to obtain clear and accurate information, and to understand the problem statement better than to do one method (Creswell \& Creswell, 2017). Participants of the quantitative study were 1016 science teacher candidates who were randomly selected from two different backgrounds (Biology and physics science). Meanwhile, the qualitative study participants were eight candidates of science teachers who were selected from the highest score in quantitative studies. The quantitative research instrument was a questionnaire consisting of study demographics, questions on the level of knowledge, and self-confidence in computational thinking skills. The questionnaire formulated in this study refers to the questionnaire administered by the previous expert (Feldhausen, Weese, \& Bean, 2018; Korkmaz, Çakir, \& Özden, 2017; Yadav et al., 2014; Yağc1, 2019). Meanwhile, the qualitative research instruments refer to the questionnaire administered by Bower (2017). Quantitative data were analyzed using descriptive statistics. Meanwhile, the qualitative data were analyzed through the formation of themes.

\section{RESULTS AND DISCUSSION Results}

Figure 1 shows the mean value of knowledge and confidence in computational thinking skills. The results show that the mean for the level of knowledge in computational thinking skill among science teacher candidates was high $($ mean $=78.54 ; \mathrm{SD}=6.48)$. Furthermore, the results of the study also found that the mean for the level of self-confidence of science teacher candidates on computational thinking skills was high $(\mathrm{min}=78.63 ; \mathrm{SD}=$ 7.03). Details are shown in figure 1: 


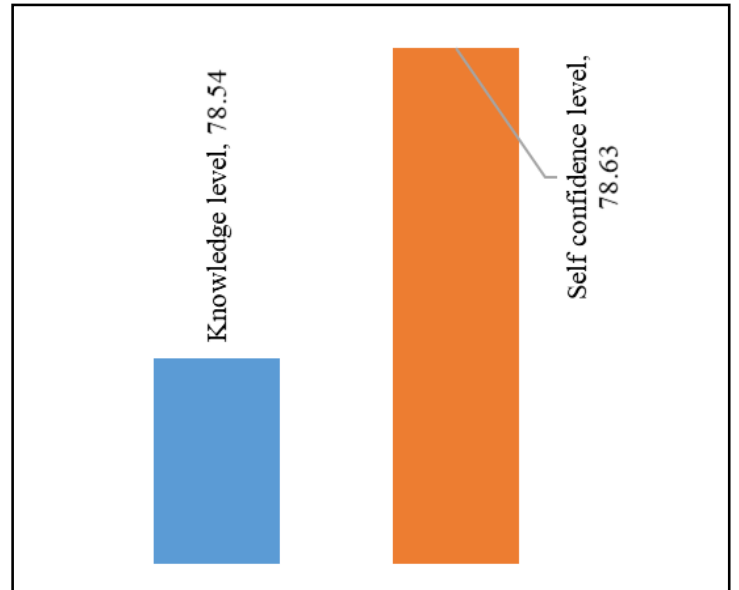

Figure 1 Mean Value of the Level of Knowledge and Self-confidence in Computational Thinking Skills

Furthermore, the findings show that the level of knowledge for each construct involved namely (1) Knowledge of CT content is high (mean $=75.00 ; \mathrm{SD}=7.73)$; (2) General pedagogical knowledge is high (mean = 79.27; $\mathrm{SD}=8.25$ ); (3) Knowledge of CT pedagogic content is very high (mean $=82.84 ; \mathrm{SD}=9.06)$; and (4) Knowledge of CT strategy is high (mean $=77.93 ; \mathrm{SD}=$ 8.02 ). The details are displayed in figure 2 below.

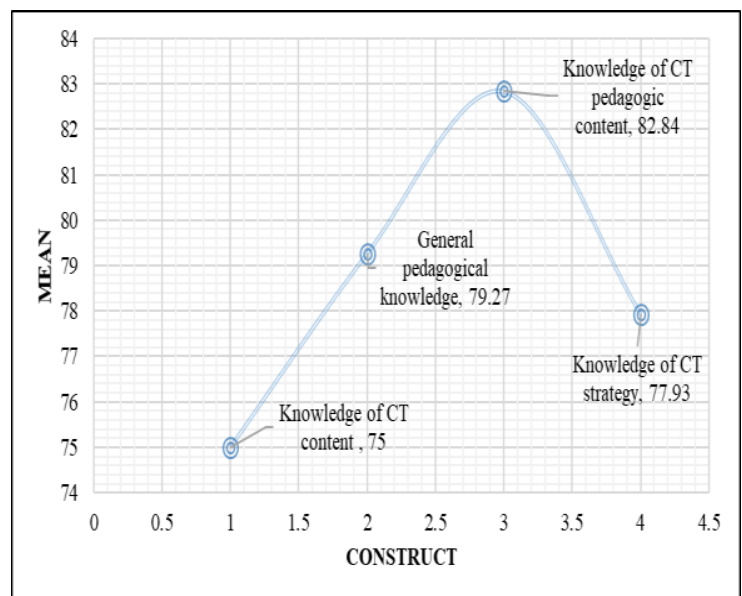

Figure 2 Mean Score of Knowledge Level Constructs on Computational Thinking Skills

The level of confidence in each construct involved, ie (1) The very high expectations $(\min =81.81 ; \mathrm{SD}=8.71) ;(2)$ High selfefficacy $(\mathrm{min}=78.48 ; \mathrm{SD}=8.87)$; (3) Higgh optimists $(\min =76.13 ; \mathrm{SD}=9.69)$; and (4)
High endurance $(\min =77.98 ; \mathrm{SD}=9.03)$; (5) High experience $(\min =78.43$; $\mathrm{SD}=$ 9.03). In details, it is shown in figure 3 :

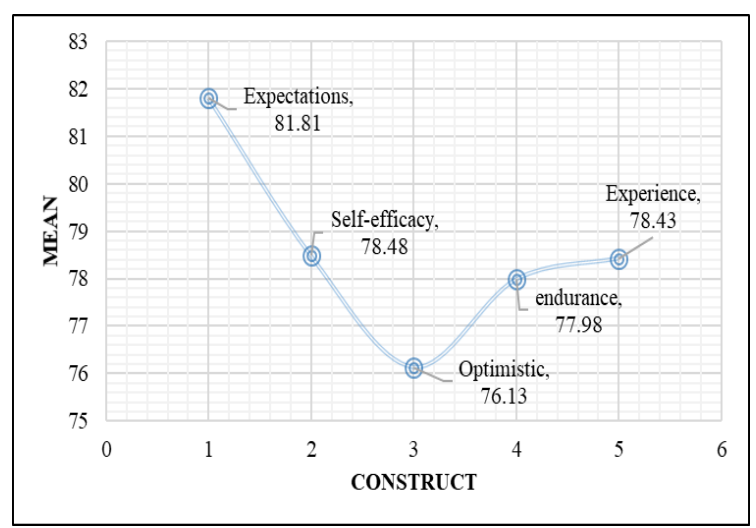

Figure 3 Mean Score of Knowledge Level Constructs on Computational Thinking Skills

Furthermore, the views of science teacher candidates on computational thinking are that they are not yet familiar with the term computational thinking. Here is an example of interview quotes obtained:

Table 1. Sample interviews

\begin{tabular}{|c|c|c|}
\hline No & $\begin{array}{l}\text { The subject } \\
\text { of the study }\end{array}$ & Interview quotes \\
\hline 1 & A & $\begin{array}{l}\text { "... Actually, I have never } \\
\text { known what } \\
\text { computational thinking } \\
\text { is. After this research, I } \\
\text { slowly began to know } \\
\text { computational thinking ". }\end{array}$ \\
\hline 2 & B & $\begin{array}{l}\text { "... In general, I have } \\
\text { never heard of so-called } \\
\text { computational thinking } \\
\text { so far, when you } \\
\text { conducted research on } \\
\text { computational thinking, I } \\
\text { tried to read one of the } \\
\text { journals that involved } \\
\text { understanding } \\
\text { computational thinking". }\end{array}$ \\
\hline
\end{tabular}

In general, this study has implications that in Indonesian education, to improve teachers' profession in the digital age can be done through the necessary skills upgrades. 


\section{Discussion}

The world of education today always changes dynamically following the times. Therefore, teachers must be willing to follow these developments to achieve better education goals as aspirations of the Indonesian people (Rahayu, Syafril, \& Wati, 2017). This is because the teacher is one of the important figures responsible for the teaching and learning process (Koç, 2015). In creating an effective teacher, the faculty of education should be able to build and produce professional teachers in their respective fields including science. Hence, current science teacher candidates are required to possess computational thinking skills, not only computational thinking skills through the use of technology such as computers, but also involving human cognitive processes in solving complex problems (Cooper, Pérez, \& Rainey, 2010; Shi, Liu, \& Hendler, 2014).

Based on the research conducted, it is found that the level of knowledge of science teacher candidates is high. This means that science teachers candidate have the essential knowledge as initial capital to teach in a real school. However, based on interviews conducted by researchers, the findings are less appropriate. The respondents' views are related to the knowledge of computational thinking skills is "not knowing," new teachers know when the researcher conducts research. The findings of this study are consistent with the study of (Bower, 2017), who found that most teachers candidate have not yet recognized the term computational thinking as the basic concept in the new digital technology curriculum. Some causes of a lack of knowledge of computational thinking skills are that teachers are less exposed to computational thinking in the early stages of their studies (Yadav et al., 2014). It is supported by (Meritxell Estebanell et al., 2017) that the cause of computational thinking skills is due to the lack of specialized knowledge.
Lack of knowledge has a negative impact on self-confidence, as in Matt \& Falkner (2015) study found that if teachers lack general understanding and knowledge of computational thinking skills, selfconfidence also decreases. In this study, most science teacher candidates define computational thinking as one of the skills that are always closely related to technology, such as computers. This view is less in line with a study by Selby \& Woollard (2014), that computational thinking is not limited to the use of technology, it is as a cognitive or mental, human, and non-mechanical process. Similarly, some experts believe that computational thinking skills are used to help to solve complex problems in human life (Aho, 2012; Wing, 2006), either using computers or involving human cognition. This is supported by CSTA \& ISTE (2011) that computational thinking is an approach to problem-solving in a way that can be implemented with computers, but is not limited to just using a computer.

In the classroom, computational thinking skills emphasize cognitive processes (Selby \& Woollard, 2014; Sung, Ahn, Kai, Choi, \& Black, 2016). Meanwhile, according to Ellis \& Tod (2013), human behavior can illustrate individual attitudes in learning because it is a strategy to promote the behavior that is needed in learning. Brennan \& Resnick (2016), also stated that the model of computational thinking skills is often used to enhance their understanding, to create relationships with others in the technology world around the individual. In addition, Powell \& Tod (2014), suggest that learning behavior reflects the social, emotional, and cognitive developments of students who depend on their previous learning experience. Based on the above views, it can be asserted that students are not only tool users but also as tool builders. According to Korkmaz et al. (2017), current students can develop their own way of thinking when they realize that computers can produce automated and effective 
solutions in solving problems. Integration of information and communication technologies is believed to meet the current generation of learning styles (Osman, Hiong, \& Vebrianto, 2013).

Furthermore, one of the constructs of knowledge is general pedagogy. According to Morine-Dershimer \& Kent (1999), general pedagogical knowledge is developed from experience. In general pedagogical knowledge, studies are high. This means that the subject has had experience in relation to that skill. Meanwhile, the findings on CT pedagogic knowledge are very high. According to Gess Newsome (1999), pedagogical content knowledge can synthesize all the necessary knowledge to become an effective teacher. Therefore, this knowledge is very important to both teachers and teacher candidates. CT pedagogical content knowledge can be developed by teachers by using existing content knowledge. Clarified by Han (2014), pedagogical content knowledge can be developed not only based on the level of understanding of knowledge but also involving the level of teacher value placed in each domain of knowledge possessed by the teacher. Since its introduction by Shulman (1987), over the past 30 years, an understanding of the manifestation and development of pedagogical content knowledge has been investigated to illustrate the dynamic nature of the construction of pedagogical content knowledge itself.

In addition, the construct of self-belief is self-efficacy and experience. Nurasika (2017), states that individuals with higher self-efficacy tend to have the ability to manage and complete assignments to achieve certain results despite difficulties. The self-confidence in this study is high. When individuals have low self-efficacy, they tend to feel the difficulty in completing the assignment given. They feel less confident and committed to carrying out their duties (Adicondro \& Purnamasari, 2011). People with high levels of self- efficacy will be more successful in their lives than people with low levels of selfefficacy (Jaengaksorn, Ruengtrakul, \& Piromsombat, 2015). In addition, in recent years Sarıcoban (2015) provides a view of self-efficacy, which is the extent to which one's own strength to accomplish the task of achieving that goal. In performing the required capabilities, it requires four types of teacher experience including experience of success and failure, physiology and affective experiences, experiences or skills and oral persuasion (Bandura, 1997; Tschannen Moran \& Gareis, 2004).

Overall, the above statement is appropriate when the knowledge and beliefs of science teacher's candidate are at a high level because previous studies on Indonesian education technology have been extensively analyzed. For example, Yuliati (2016) who developed learning models for physics teachers, the study from Gunawan, Harjono, \& Sutrio (2017) about interactive multimedia teacher candidates, use of technology, information and communication, Internet-based learning (Effendi, 2016; Farida, 2012; Siahaan, 2012), and e-learning (Batubara, 2017; Sari, Gunawan, \& Harjono, 2017; Siswanto, Saefan, Suparmi, \& Cari, 2016; Thomas \& Setiaji, 2014). Teacher candidates justify their understanding of computational thinking related to technology. The presence of students has also been widely introduced to technology. For example, the study of Safrudin, Trisnamansyah, Makmun, \& Darmawan (2019) about technology-based learning to improve student independence, Kamil, Amin, Saidin, \& Upe (2019), and Mardhiyana \& Nasution (2019) in the fourth industrial era. In addition, Gunawan, Harjono, Sahidu, \& Gunada (2019) conducted training related to the utilization of information and communication technology.

\section{CONCLUSION}

In conclusion, this study is very important to know exactly about the 
knowledge and self-confidence of the computational thinking skills possessed by a science teacher candidate. If given the opportunity to carry out serious training from time to time, prospective teachers can improve their knowledge and the rest improve their self-esteem in computational thinking skills. Therefore, all parties involved in the education world in Indonesia should work together to increase their knowledge and confidence in computational thinking as one of the $21 \mathrm{st}$ century basic skills.

\section{REFERENCES}

Adicondro, N., \& Purnamasari, A. (2011). Efikasi Diri, Dukungan Sosial Keluarga dan Self Regulated Learning pada Siswa Kelas VIII. Jurnal Humanitas, 8(1), 17-27.

Aho, A. V. (2012). Computation and Computational Thinking. The Computer Journal, 55(7), 832-835.

Angeli, C., \& Jaipal Jamani, K. (2018). Preparing Pre-service Teachers to Promote Computational Thinking in School Classrooms. In Computational Thinking in the STEM Disciplines (127-150). Springer.

Bandura, A. (1997). Self-Efficacy, The Exercise of Control. Freeman and Company: New York.

Barr, V., \& Chris, S. (2011). Bringing computational thinking to K-12: What is involved and what is the role of the computer science education community? ACM Inroads, 2(1), 4854.

Batubara, H. H. (2017). Pengembangan Situs e-Learning dengan Moodle versi 3.1 sebagai Media Pembelajaran pada Program Studi Pendidikan Guru Madrasah Ibtidaiyah. Jurnal Al Bidayah, 9(1).

Belanger, C., Christenson, Hannah, \& Lopac, K. (2018). Confidence and Common Challenges: The Effects of Teaching Computational Thinking to Students Ages 10-16. Sophia, the St.
Catherine University Repository.

Bower, M. (2017). Self-Confidence Questionaire.

Bower, Wood, L. N., Lai, J. W., Howe, C., Lister, R., Mason, R., ... Veal. (2017). Improving the Computational Thinking Pedagogical Capabilities of School Teachers. Australian Journal of Teacher Education, 42(3). https://doi.org/http://dx.doi.org/10.14 221/ajte.2017v42n3.4

Cooper, S., Pérez, L. C., \& Rainey, D. (2010). K--12 computational learning. Communications of the ACM, 53(11), 27-29.

Creswell, J. W., \& Creswell, J. D. (2017). Research design: Qualitative, quantitative, and mixed methods approaches. Sage publications.

CSTA, \& ISTE. (2011). Computational Thinking in $\mathrm{K}-12$ Education Leadership Toolkit.

Department for Education England. (2014). The National Curriculum in England Key Stages 3 and 4 Framework Document.

Effendi, M. (2016). Integrasi Pembelajaran Active Learning dan Internet-Based Learning dalam Meningkatkan Keaktifan dan Kreativitas Belajar. Nadwa, 7(2), 283-309.

Ellis, S., \& Tod, J. (2013). Behaviour for Learning: Proactive Approaches to Behaviour Management. Routledge, Oxon, UK.

Endarta, A. (2014). Pembelajaran Kurikulum 2013.

Erdogan, M. N., \& Koseoglu, F. (2012). Analysis of High School Physics, Chemistry and Biology Curriculums in Terms of Scientific Literacy Themes. Educational Sciences: Theory and Practice, 12(4), 2899-2904.

Farida, I. (2012). Interkoneksi Multipel Level Representasi Mahasiswa Calon Guru pada Kesetimbangan dalam Larutan melalui Pembelajaran Berbasis Web. Disertasi: Universitas Pendidikan Indonesia. 
Feldhausen, R., Weese, J. L., \& Bean, N. H. (2018). Increasing Student SelfEfficacy in Computational Thinking via STEM Outreach Programs. Paper Session: Computational Thinking. Baltimore, MD, USA. https://doi.org/https://doi.org/10.1145/ 3159450.3159593

Figueiredo, Q., \& Alberto, J. (2017). How to Improve Computational Thinking: a Case Study Education in the Knowledge Society. Universidad de Salamanca Salamanca, España, 18(4), 35-51.

Gess Newsome, J. (1999). Pedagogical content knowledge: An introduction and orientation. In Examining pedagogical content knowledge (317). Springer.

Grover, \& Pea, R. (2013). Computational thinking in $\mathrm{K}-12$. A review of the state of the field. Educational Researcher, 42(1), $38-43$. https://doi.org/https://doi.org/10.3102/ 0013189X12463051

Gunawan, G., Harjono, A., Sahidu, H., \& Gunada, I. W. (2019). Pelatihan Pemanfaatan Teknologi Informasi Bagi Guru Ipa Fisika Di Lombok Barat. Jurnal Pendidikan Dan Pengabdian Masyarakat, 2(1).

Gunawan, G., Harjono, A., \& Sutrio, S. (2017). Multimedia Interaktif dalam Pembelajaran Konsep Listrik bagi Calon Guru. Jurnal Pendidikan Fisika Dan Teknologi, 1(1), 9-14.

Han, S. W. (2014). The role of teacher efficacy in the development of pedagogical content knowledge among experienced science teachers (Doctoral dissertation). Texas Scholar Work. The University of Texas at Austin.

Jaengaksorn, N., Ruengtrakul, A., \& Piromsombat, C. (2015). Developing self-efficacy and motivation to be a teacher scale, Thai version. In Procedia-Social and Behavioral Sciences, 171, 1388-1394.
Jeongwon, C., Sangjin, A., \& Youngjun, L. (2015). Computing education in Korea current issues and endeavors. ACM Transactions on Computing Education (TOCE), 15(2), 8.

Josip, P. N., \& Sinambela, M. (2013). Kurikulum 2013 dan Implementasinya dalam pembelajaran. Generasi Kampus, 6(2).

Kamil, S. U. R., Amin, H., Saidin, S., \& Upe, A. (2019). The Implementation of Information and Communication Technology on Learning Process in Communication Department of UHO Facing Industrial Revolution 4.0. Proceeding of Community Development, 2, 344-352.

Koç, E. S. (2015). An evaluation of the effectiveness of committees of teachers according to the teachers' views, Ankara province sample. Procedia-Social and Behavioral Sciences, 174, 3-9.

Korkmaz, Ö., Çakir, R., \& Özden, M. Y. (2017). A validity and reliability study of the computational thinking scales (CTS). Computers in Human Behavior, 72, 558-569. https://doi.org/10.1016/j.chb.2017.01. 005

Long, X., Jiehui, Z., \& Zhanli, L. (2013). The design of teaching structure based on competency training of computational thinking. In Proceedings of the International Conference on Education Technology and Information System (ICETIS 2013). Amsterdam, The Netherlands: Atlantis Press.

Machali, I. (2014). Kebijakan Perubahan Kurikulum 2013 dalam Menyongsong Indonesia Emas Tahun 2045. Jurnal Pendidikan Islam, 3(1), 71. https://doi.org/10.14421/jpi.2014.31.7 $1-94$

Mardhiyana, D., \& Nasution, N. B. (2019). Kesiapan Mahasiswa Pendidikan Matematika Menggunakan ELearning Dalam Menghadapi Era 
Revolusi Industri 4.0. In Seminar Nasional Pendidikan Matematika Ahmad Dahlan, 6.

Matt, B., \& Falkner, K. (2015). Computational thinking, the notional machine, pre-service teachers, and research opportunities. In Proceedings of the 17th Australasian Computing Education Conference (ACE 2015), 27.

Meritxell Estebanell, M., Juan González, M., Marta Peracaula, B., \& Víctor Lopez, S. (2017). About The Concept Of Computational Thinking And Its Educational Potentialities By PreService Teachers. In Proceedings of EDULEARN17 Conference 3rd-5th July 2017. Barcelona, Spain.

Morine-Dershimer, G., \& Kent, T. (1999). The complex nature and sources of teachers' pedagogical knowledge. In Examining pedagogical content knowledge, Springer, 21-50.

Nurasika. (2017). Analysis Of Self-Efficacy Against The Application Of Environmental Education Across The Curriculum In Science Teachers In Johor Bahru. Fakulti Pendidikan Universiti Kebangsaan Malaysia.

Osman, K., Hiong, L. C., \& Vebrianto, R. (2013). 21st century biology: an interdisciplinary approach of biology, technology, engineering and mathematics education. ProcediaSocial and Behavioral Sciences, 102, 188-194.

Ozcinar, H. (2017). Bibliometric analysis of computational thinking. Educational Technology Theory \& Practice, 7(2), 149-171.

Powell, S., \& Tod, J. (2014). A Systematic Review of How Theories Explain Learning Behaviour in School Contexts, EPPI-Centre, Social Science Research Unit. Institute of Education, University of London.

Rahayu, T., Syafril, S., \& Wati, W. (2017). Pengembangan Lembar Kerja Siswa (LKS) IPA Terpadu Menggunakan
Kooperatif Tipe STAD, 1-6.

Safrudin, M., Trisnamansyah, S., Makmun, T. A. S., \& Darmawan, D. (2019). Pengembangan Pembelajaran Model Blended Computer Based Learning (BCBL) Tentang Turunan Fungsi untuk Meningkatkan Kemandirian Belajar Siswa SMA. In Prosiding Seminar Nasional Pendidikan KALUNI (Vol. 2).

Sands, P., Yadav, A., \& Good, J. (2018). Computational Thinking in K-12: Inservice Teacher Perceptions of Computational Thinking. In Computational Thinking in the STEM Disciplines. Springer, 151-164.

Sari, P. I., Gunawan, G., \& Harjono, A. (2017). Penggunaan Discovery Learning Berbantuan Laboratorium Virtual pada Penguasaan Konsep Fisika Siswa. Jurnal Pendidikan Fisika Dan Teknologi, 2(4), 176-182.

Sarıcoban, G. (2015). Academic SelfEfficacy Beliefs of Pre-Service Elementary School Teacher Candidates. Procedia-Social and Behavioral Sciences, 186, 28-32.

Selby, \& Woollard. (2014). Refining an understanding of computational thinking.

Sentance, S., \& Andrew, C. (2015). Teachers' perspectives on successful strategies for teaching Computing in school. Paper presented at IFIP TCS.

Shi, W., Liu, M., \& Hendler, P. (2014). Computational Features of the Thinking and the Thinking Attributes of Computing: On Computational Thinking. JSW, 9(10), 2507-2513.

Shulman, L. (1987). Knowledge and teaching: Foundations of the new reform. Harvard Educational Review, 57(1), 1-23.

Siahaan, S. M. (2012). Penggunaan Teknologi Informasi dan Komunikasi dalam Pembelajaran Fisika. In Prosiding Seminar Nasional Fisika Universitas Sriwijaya, 4 Juli 2012.(Energi, Lingkungan, dan 
Teknologi Masa Depan: Tantangan dan Peluang Ilmu Fisika), 13-20. PT. Mitra Intimarga.

Siswanto, J., Saefan, J., Suparmi, S., \& Cari, C. (2016). The effectiveness of eLab to improve generic science skills and understanding the concept of physics. Jurnal Pendidikan Fisika Indonesia, 12(1), 33-40.

Sung, Ahn, Kai, S. M., Choi, A., \& Black, J. B. (2016). Incorporating touchbased tablets into classroom activities: fostering children's computational thinking through ipad integrated instruction, in: Handbook of Research on Mobile Learning in Contemporary Classrooms. IGI Global, 378-406. https://doi.org/http://dx.doi.org/10.40 18/978-1-5225-0251-7.ch019

Thomas, P., \& Setiaji, K. (2014). ELearning Dengan Pendekatan Kooperatif Tipe Jigsaw Untuk Meningkatkan Aktivitas Dan Hasil Belajar Mahasiswa. Dinamika Pendidikan, 9(1).

Titik, R., \& Kamisah, O. (2018). Early Study: Self-Confidence on the Computational Thinking Skills Among Science Teacher Candidates. In The 5th International Conference on Islam and Higher Education (5th ICIHE 2018). Padang, Indonesia.

Tschannen Moran, M., \& Gareis, C. R. (2004). Principals; s sense efficacy: Assessing a promiseing construct. Review of Educational Research, 68(2), 202-248.

Wing, J. (2006). Computational Thinking. Communications of the Association for Computing Machinery (ACM), 49(3), 33-35.

Wing, J. (2011). Research notebook: Computational thinking: What and why? The Link Magazine, Spring. Carnegie Mellon University, Pittsburgh.

Wu, M. L. (2018). Educational Game Design as Gateway for Operationalizing Computational
Thinking Skills among Middle School Students. International Education Studies, 11(4), 15.

Yadav, A., Mayfield, C., Zhou, N., Hambrusch, S., \& Korb, J. T. (2014). Computational thinking in elementary and secondary teacher education. ACM Trans. Comput. Educ, 14(1), 16.

Yadav, A., Zhou, N., Mayfield, C., Hambrusch, S., \& Korb, J. T. (2011). Introducing Computational Thinking in Education Courses, (42), 9-12.

Yağcı, M. (2019). A valid and reliable tool for examining computational thinking skills. Education and Information Technologies, 24(1), 929-951.

Yuliati, L. (2016). Pengembangan model pembelajaran untuk meningkatkan kemampuan mengajar calon guru fisika. Jurnal Ilmu Pendidikan, 14(1). 